anbiances Environnement sensible, architecture et espace urbain Varia | 2017

\title{
Tectonic perspectives for urban ambiance? Towards a tectonic approach to urban design
}

Perspectives tectoniques d'une ambiance urbaine? Vers une approche tectonique du design urbain

Elias Melvin Christiansen, Lea Holst Laursen and Marie Frier Hvejsel

\section{(2) OpenEdition}

\section{Journals}

Electronic version

URL: http://journals.openedition.org/ambiances/886

DOI: 10.4000/ambiances.886

ISSN: 2266-839X

\section{Publisher:}

Direction Générale des Patrimoines - DAPA - MCC, UMR 1563 - Ambiances Architectures Urbanités (AAU)

\section{Electronic reference}

Elias Melvin Christiansen, Lea Holst Laursen and Marie Frier Hvejsel, « Tectonic perspectives for urban ambiance? Towards a tectonic approach to urban design », Ambiances [Online], Varia, Online since 10 October 2017, connection on 19 April 2019. URL : http://journals.openedition.org/ambiances/886 ; DOI : 10.4000/ambiances.886

This text was automatically generated on 19 April 2019

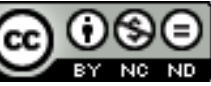

Ambiances is licensed under a Creative Commons Attribution-NonCommercial-NoDerivatives 4.0 International License. 


\title{
Tectonic perspectives for urban ambiance? Towards a tectonic approach to urban design
}

\author{
Perspectives tectoniques d'une ambiance urbaine? Vers une approche \\ tectonique du design urbain
}

Elias Melvin Christiansen, Lea Holst Laursen and Marie Frier Hvejsel

\section{Introduction}

1 A series of environmental and societal challenges influences urban developments, to which they have to respond and adapt. In particular, in recent years, radical challenges related to climate change have been emerging as critical issues for the urban environment, in that they tend to undermine city life as it is experienced and the liveability of the city. This calls for renewed engagement with the fragile but vital question of the ambiance of the built environment. Specifically, we are experiencing a decline in resources, we need improved protection against the climate, and action is required to deal with pollution (UNU-IHDP \& UNEP, 2012; EM-DAT, 2016; WHO, 2016). Today, these conditions are usually considered as a common agenda, in accordance with which all cities are managed and developed. Thus, the challenge of tomorrow comes from the comprehensive increase in population in central agglomerations identified around the world: the challenge of urban densification. Never before have cities had to deal with immigration to the extent we see today (UN, 2014). Cities are expanding upwards and outwards, and the sustainable solutions practised today need to be scaled up to accommodate the prospects of future urban populations. Consequently, the main question posed to architects and urban designers is: how are sustainable designs realised as complex layered technical solutions, while still creating liveable, sensory and experience-rich urban environments? 
2 The term 'liveability' attempts to contain in a single word the qualities that citizens desire and expect their cities to bring to their everyday urban life. But what is liveability? Interpretations of a liveable city can include how well the city lives in relation to resilience and adaptability; it can describe the quality of life within the city in relation to urban life and ambiances, or it can measure how attractive the city is to live in, in relation to the qualities of the built environment. Seemingly, none of these interpretations can be ignored, so a liveable city should include fragments of all of them. The notion of liveability as a measure of overall quality of life is related to Jan Gehl's Life between buildings and Cities for people (Gehl, 1987; Gehl, 2010). Liveability, as a measure of the quality of life in the city and the attractiveness of living in a city, is related to the way we perceive our physical surroundings. In architecture, this includes the quality of space, and in urban design it is expressed in tactility, materiality, and sensory experiences in relation to work on phenomenology and atmospheres by Juhani Pallasmaa, Gernot Böhme, and Peter Zumthor (Pallasmaa, 2005; Böhme, 1998; Zumthor, 2006). Thus, the question of improving the liveability of the urban environment that forms the scope of the present paper is intimately linked to the delicate notion of ambiance understood as a means for describing the atmosphere of a given space. Hence, succeeding in increasing the ambiance of urban space within the context of climate change and urban densification entails the intimate linking of architecture and urban design sought by Mohsen Mostafavi:

“...one could argue that the traditional divisions between architecture, landscape architecture, planning, and urban design are still necessary for the formation and accumulation of specific disciplinary knowledge. But each individual discipline is of limited value in responding to the range and diversity of contemporary urban issues." (Mostafavi, 2010, p. 29)

3 This paper takes its point of departure in the observation that architects and urban designers should jointly approach urban challenges as opportunities to rethink, redefine, and redesign how we as humans live in our cities. Instead of dealing with climate prospects and urban densification as even more conditions to comply with, this perspective provides a potential for developing new continuous, liveable environments for citizens through an integration or linkage across the architectural and the urban domains. Examined in that context, urban and architectural sustainable developments become more than technological answers, as the focus becomes that of thriving, and not just surviving (Appleyard et al, 2013). However, whereas theories of landscape urbanism provide a general framework for thinking of the urban fabric as a continuous horizontal carpet that links land, infrastructure and built volumes, the question of how this landscape is materialised at the architectural and human scale when actually constructed is less developed. In architectural theory, the notion of tectonics has, since its emergence in ancient Greece, been applied and developed as a means to unite aesthetics and technique in the creation of architecture. Specifically, the act of integrating structural elements intentionally for the experience of the end work and mastering the material properties and techniques applied in its realisation has been emphasised (Semper, 1989, 1851; Semper, 2004, 1861; Sekler, 1964; Frascari, 1984; Frampton, 1995). It is our observation that tectonic theories in architecture thus link to the question of architectural atmospheres dealt with by Böhme, Pallasmaa, and Zumthor, and to the actual constructive joining of structural elements at the architectural scale. Thus, there is also the possibly of positioning tectonics in relation to the aforementioned pressing technical challenge that governs the development of the built environment as a whole, 
across the architectural and urban scales. Continuing this line of thought, the paper identifies a potential to develop the theory of landscape urbanism further, by juxtaposing it with tectonic architectural theory, thereby pursuing the outline of an analytical framework that bridges the urban and architectural concept of ambiance. The paper investigates this potential, by studying whether it is possible to circumscribe and define urban ambiances in relation to the concept of the built environment across scale when applying an 'urban tectonic' perspective.

\section{Method}

Methodologically, the potential of such an 'urban tectonic' framework is examined by applying it to a study of a tertiary building development; in this case a bank, a typology not usually designed explicitly to influence urban liveability, let alone provide urban ambiance. The bank and its accompanying landscape in Copenhagen are designed by a collaboration of architects, urban designers and landscape architects. And in this building, architecture and the urban landscape seem to merge into a fertile scenery of urban ambiances, while simultaneously answering functional and technical demands for parking, rainwater management, and protection from heat and wind. This intriguing urban landscape immediately attracts passers-by, who realise that this is a portal, a gateway into an even bigger urban experience, which lures one with an enchanting urban ambiance that is expressed even in its smallest furnishing details. The case study operates on two parallel tracks: a theoretical track that studies the potential for conceptually linking landscape urbanism and tectonic architectural theory, and an analytical track that studies whether this framework can be applied in analysing the unique ambiance of the bank. With this case study design, intersections of theory and analytical observations of a practical example provide a framework for capturing and describing urban ambiances in relation to the construct of the built environment across scale. The two theoretical points of view, landscape urbanism and tectonic architectural theory respectively, represent two different and not traditionally related fields. However, where landscape urbanism on the one hand addresses the urban landscape as surface and process, tectonic theory conceives architecture as a combination of structure and form. Thus, there is a potential for the two seemingly opposite theories to supplement each other. As a way of guiding the analysis, the theoretical positions are used to describe and understand the case. Analytically, the case study is examined through site visits and drawings and records of form, structure, surface and coherence, using the architectural section as a method to capture the relation between building and landscape. As a conclusion to this conceptual and analytical case study, the paper discusses the perspectives of 'urban tectonics' as a possible route towards improving the ambiance of urban space.

\section{A case study}

Rising up within a row of tall, anonymous office towers, pierced by a six-lane traffic artery to the inner city of Copenhagen, this building grabs your attention by presenting a notable contrast to the surrounding spatial monotony, which draws little or no attention from the average citizen. Dressed as a fertile mountain hillside, this development would have succeeded in fooling you into reading the space as anything but a bank, if the sign 
above the door had not displayed this information. Could this be an example of a tectonic approach to urban design? (see illustration 1).

Following the abandonment of a former railway station facility and general urban depletion along Kalvebod Brygge in Copenhagen, initiatives during the 2000s were taken to regenerate the area into a denser and more attractive urban district, integrating public functions, commercial developments, and dwellings (Københavns Kommune, 2006). The context is composed of three main areas: the still active railway tracks of the nearby Copenhagen Central Station, the edge of the traditional inner city containing urban blocks, and the more recent harbour front development containing office buildings from the early 2000s. The main urban concept for the regeneration scheme is to use buildings as enclosures of a continuous public, green landscape extending from Bernstorffsgade to Dybbølsbro through a set of new developments and existing buildings. In this plan, situated on the first site encountered from the inner city, the bank development could be perceived as a gateway into this new green, urban landscape (see illustration 2).

7 The winning project was a collaboration between Lundgaard \& Tranberg architects and SLA landscape architects, two Danish design offices highly acknowledged for their professional concern for high quality. The design consists of two opposing office buildings, 10 storeys tall, with a sloping artificial green scenery between them, elevated 7 metres from ground level (see illustration 3 ).

The two buildings are described by the architects as:

"...shaped to accommodate the location and views of the harbour and city. A flexible building structure gives spatial, well-lit working areas placed around the cylindrical cores, in which stairs, elevators, toilets and technical shafts are located... ...the facades have storey-high glass sections in an alternating compositional rhythm with characteristic retracted floor structures coated with copper." (Lundgaard \& Tranberg, 2017)

9 The artificial, green scenery between the towers, referred to by the landscape architects as the city dune, is described as:

“...The City Dune is inspired by nature's processes and built up as a Swedish hill side with a terrain that rises from street level to the second floor level, covering the side and the roof of the bank's parking garage. The white concrete surfaces reflect the sun while all rain water is collected and re-used for irrigation and cooling of the urban space in summer. The Nordic vegetation and trees provides shade on hot summer days and shelter when it rains. At the same time the City Dune provides SEB Bank with a strong and unique Nordic identity." (SLA, 2017)

10 With references to Swedish nature, the client's natural and cultural heritage, the ambient appearance of the space draws its inspiration from a mountainside with trees, plants, ferns, and moss, but here elegantly placed in an urban scene. 
Illustration 1: SEB bank in context

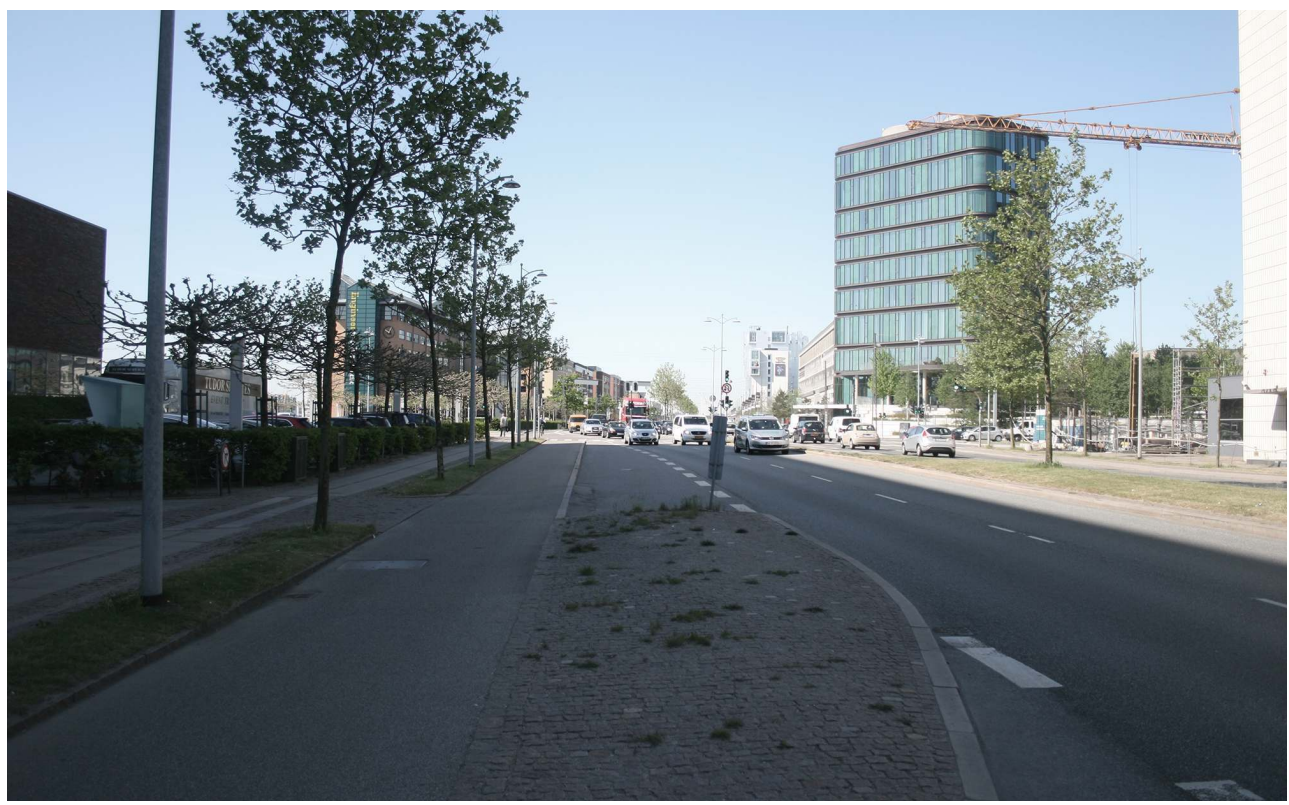

SOURCE AND COPYRIgHT: AUTHORS.

Illustration 2: Contextual drawing1-10.000

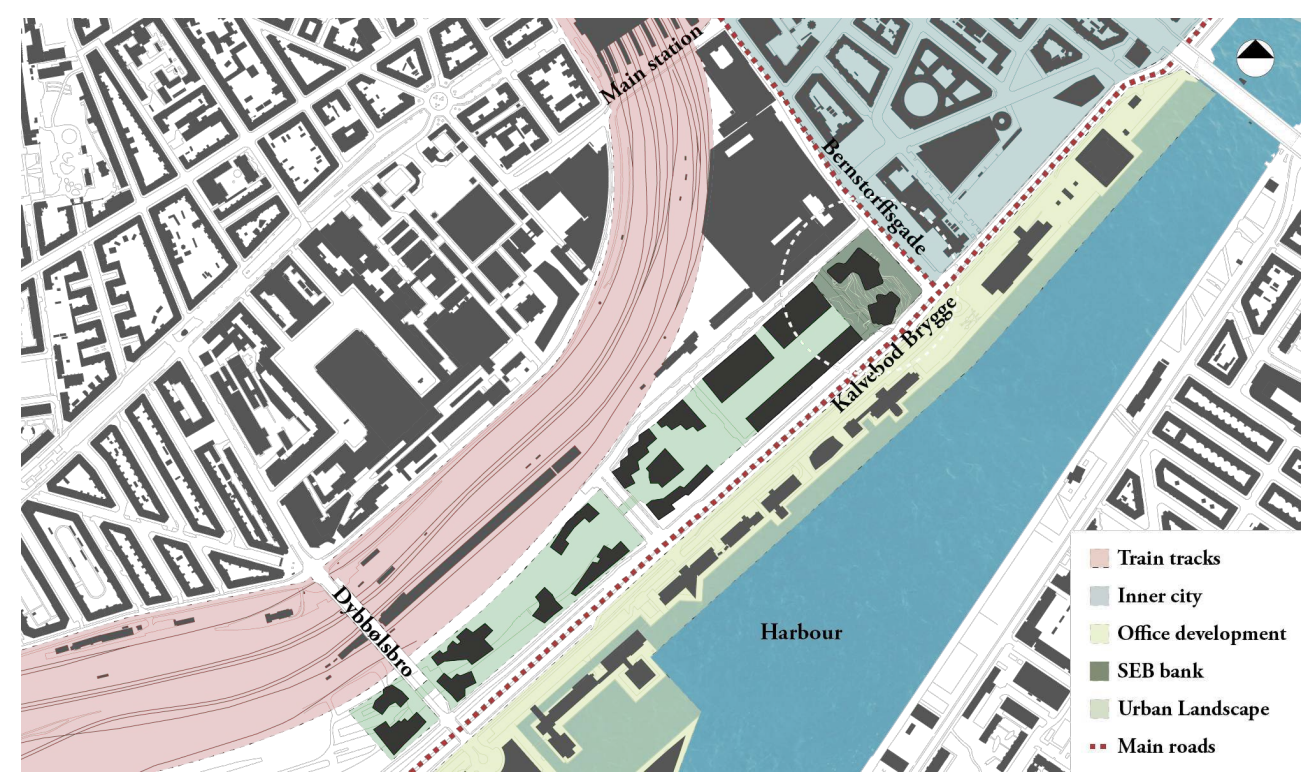

SOURCE AND COPYRIgHT: AUTHORS. 


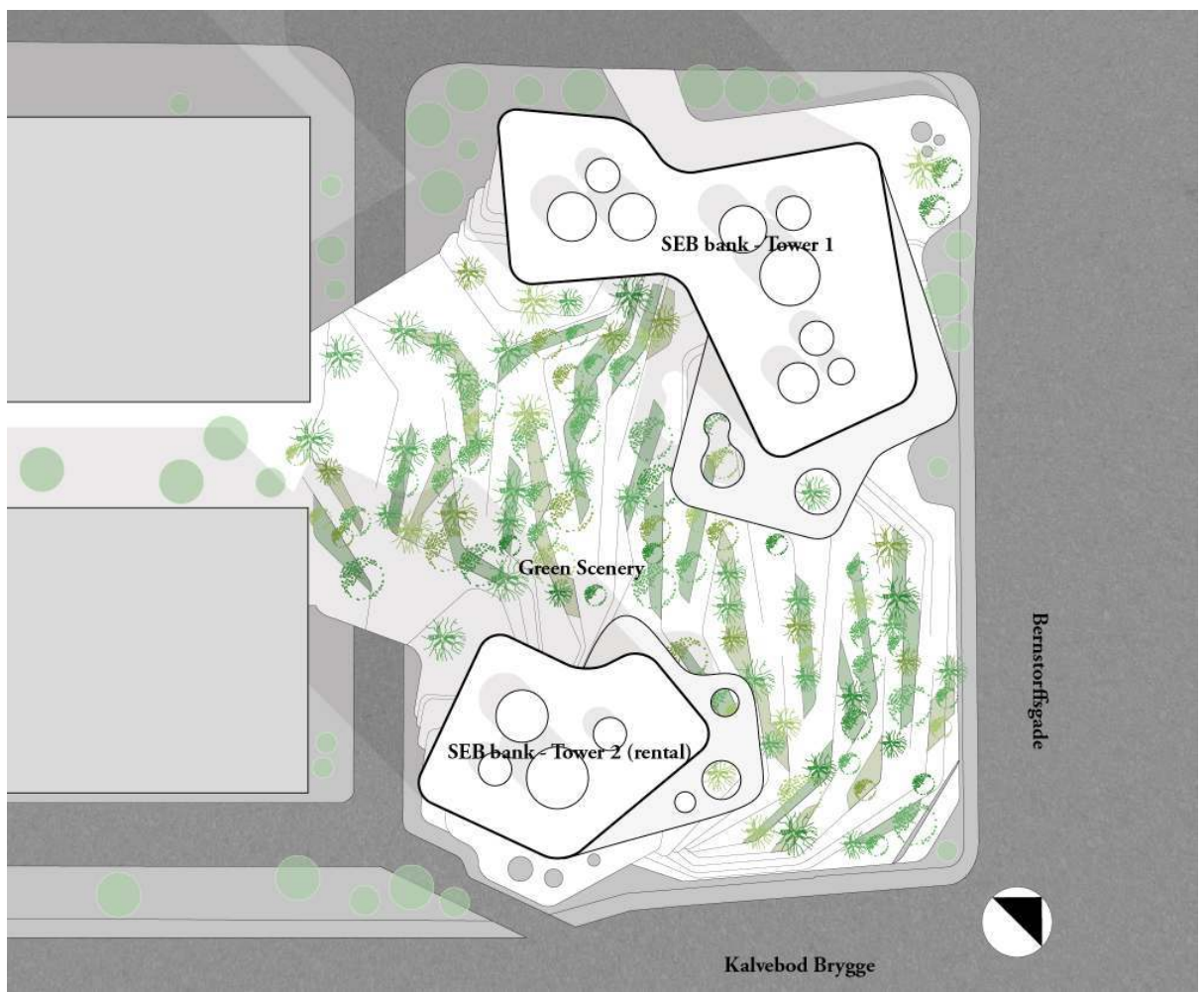

SOURCE AND COPYRIgHT: AUTHORS.

\section{Urban tectonics as a theoretical and analytical framework?}

11 It is obvious that something happens in the bank, but we are not able to describe it fully at first glance. There seems to be something understood as ambiance, or liveability, derived from joining architecture and urban design. In the following, we will elaborate and see if this joint perspective can help us describe it more accurately. We notice from our observations that we are dealing with urban landscapes, and spatial qualities that are closely related to the materials and structural systems applied. We thus seek answers in the theoretical notions related to landscape urbanism and tectonic architectural theory. Does it make sense to describe the unique ambiance of the bank by means of a linkage between the two?

\section{Landscape urbanism and tectonic architectural theory}

Landscape Urbanism originated from an increased environmental awareness, a recognition of the suburban landscape as sprawl; a change of perspective towards landscape, and not buildings, as the glue that ties cities together; and a registration of traditional urban centres in dissolution, predominantly linked together in network cities (Corner, 1999; Mostafavi, 2003; Waldheim, 2006, Waldheim, 2016). It initially represented a combination of approaches from landscape architecture, urban design, and architecture to designing cities. Academically, it grew out of the Landscape Urbanism Symposium in 1997 organised by Charles Waldheim, and followed a general rejection of the modernist 
movement, but was especially concerned with a lack of liveability in modernist cities. Furthermore, landscape urbanism criticised architecture for its inability to offer a coherent account for understanding the urban situation, especially evident in decentralised, industrial development, leaving large urban wastelands in historic inner cities (Waldheim, 2006). Compared to landscape urbanism, the development of tectonic theories in architecture has had a longer journey. The contemporary understanding owes credit to Kenneth Frampton's comprehensive Studies in tectonic cultures (Frampton, 1995). Frampton's view on tectonics can be traced back to industrialisation in the 1850s, where the intention emerged from technological evolution and a curiosity about how architects could meaningfully relate to this development, as exemplified in Gottfried Semper's seminal writings (Semper, 1989, 1851; Semper, 2004, 1861). The notion of tectonics is often associated with the Vitruvian triangle of strength, utility, and beauty, but is also seen as a critical means in discussing the role and responsibility of the architect, and herein a meaningful development and application of technology. Hence, when considering the current urban challenges outlined in the introduction, which are strongly related to technological development, a recalling of tectonic theory, and specifically that of positioning the notion in relation to urban design, appears evident. As we are entering a different technological era, where the premise seems to have changed from striving for technological progress towards striving for technology in balance, it is our observation that there is a need to sharpen our theoretical argument by relating it closely to the analysis of practical observations.

13 Landscape urbanists argue that traditional urban design is too inflexible, too slow, and too costly to deal with the current urban culture of constant flux (Waldheim, 2016). Landscape urbanism understands the city as an ever-changeable urban landscape, describing not only landscape as more than open green areas; but also, architecture and infrastructure can be described by the notion of landscape (Wall, 1999; de Geyter, 2002). Thus, the landscape is a medium, a method for understanding urban fluctuation, adaptations, temporality, and transformations, because landscape as a metaphor is the most appropriate for containing the ever-changeable urban landscape and its openendedness and indeterminacy (Corner, 2006; Waldheim, 2006; Waldheim 2016). The landscape urbanist's approach seeks to capture and transform the site, while retaining manifoldness and contingency in the design process:

"The promise of landscape urbanism is the development of a space-time ecology that treats all forces and agents working in the urban field and considers them as continuous networks of interrelationships." (Corner, 2006, p. 30)

Landscape urbanists understand cities as open-ended where design is concerned, with staging of the surfaces that connect the urban tissue. By staging the surface, new relationships, new meetings, and new opportunities are created; buildings and landscapes are juxtaposed with equal importance (Waldheim, 2006; Corner, 2006). The urban surface is the all-inclusive ground-plane "that accommodates buildings, roads, utilities, open spaces, neighborhoods, and natural habitats" (Wall, 1999, p. 223). When dealing with the ever-changing city, the principle of staging the urban surface becomes a means with which to bind the city together, and a reaction to temporality, transformation, and adaptation (Waldheim, 2016). Looking at the SEB bank in this perspective, one experiences the green scenery as an urban surface that has been staged and that binds the buildings, the urban space and the city together. By manipulating the concrete elements in the surface, new spatial experiences and relationships have been created, and by blurring the distinction between public and private, an attractive urban ambiance 
between traditional architecture and urban design appears. Below the green scenery, there is a parking garage servicing the towers. Here, a functional demand for parking and technical demands for rainwater management and wind barriers are solved by constructing a partially underground parking garage, topped with artificial green urban scenery. Vegetation is used as windbreaks, to decrease the albedo effect and to manage rainwater, but also to nurture an ambiance that seemingly enhances the liveability for the workers in the office towers, as well as for citizens who are likewise generously invited to enjoy the space. The green scenery contains a rich diversity of trees and grasses, but also distinctive spatial experiences. At a general level, this approach to design, where the specific design solution solves technical challenges and provide qualities of ambiance, can be associated with a tectonic approach to design (see illustration 4).

Illustration 4: The urban scenery

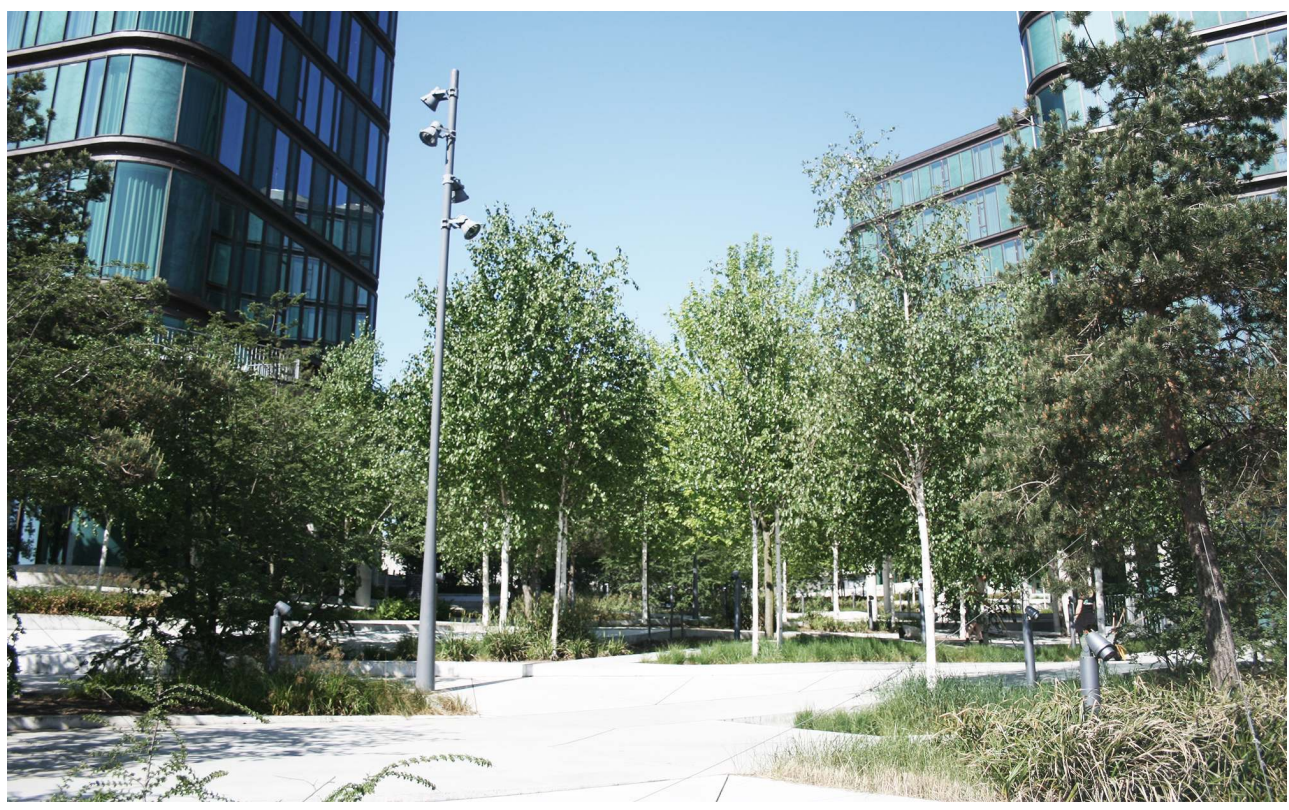

SOURCE AND COPYRIgHT: AUTHORS.

\section{Poetry of construction across scale}

15 Kenneth Frampton's widespread definition of the notion of tectonics as the poetry of construction frames this overall notion of linking the spatial concept of the project closely to its functional and practical needs and construction technique (Frampton, 1995). From that, tectonic theories in architecture can be understood to be related to a poetic execution of structure, a juxtaposition of aesthetics and technology. Frampton builds his definition upon, among others, Eduard F. Sekler's distinction between structure, construction, and tectonics:

"When a structural concept has found its implementation through construction, the visual result will affect us through certain expressive qualities which clearly have something to do with the play of forces and corresponding arrangement of parts in the building, yet cannot be described in terms of construction and structure alone. For these qualities... the term tectonic should be reserved." (Sekler, 1964, p. 89) 
Thus, whilst it is often associated with the technical dimension of architecture as such, tectonics describes something unmeasurable, the experienced qualities being derived from the expression of structure and construction, rather than the construction itself as a physical instance. This experience can be associated with the notion of empathy. The experience read from the physical forces of architectural construction provokes an empathetic reaction, forcing the observer's own experiential participation in the surroundings (Sekler, 1964). Empathy, in art theory, is a notion describing the phenomenon that we, as rational individuals, read certain moods in the experience of our surroundings, understood here as ambiances, but also relates to the process of architectural creation (Vischer, 1994, 1873; Wölfflin, 1994, 1886). From this perspective, tectonics captures the sensuous and emotional experience registered within the observer from his or her surroundings, i.e. architecture and urban design, and thus describes a possible link between the two, that stems from an empathetic vision on the part of the architect/urban designer. A connection to Gernot Böhme and his writings on atmospheres is recognisable in this interpretation (Böhme, 1998). Architects are limited by material qualities and by natural forces, but through ingenuity and virtuosity we can join elements in just that specific way to achieve the desired expressive end. And rarely, but sometimes, that specific end touches us as individuals, in which we are able to recognise a projection from something within ourselves: an "expression of a sentient soul" (Wölfflin, 1994, 1886, p. 152). This is where we believe architecture distinguishes itself from mere buildings. Hence, by describing a link between the aesthetic experience and the technical ingenuity and means applied in the realisation of architectural space, the notion of tectonics forces a critical questioning of our role as architects and urban designers in this matter. In the case of the analysis of the SEB bank, this could be exemplified by looking at the interpretation of the two opposing buildings as a gateway into the green landscape that fuses the aesthetic experience of the buildings as a space with the technical inventions applied in the sloping concrete construction. This is a materialised detail, where the deliberate shaping of structural elements makes us read it in a certain way: as a gateway that invites us in. It makes sense to describe the technological and functional solution of the parking garage below, with the artificial green scenery above, as a poetic approach to design and application of technology, with enriched urban ambiance as a result in the case of the SEB bank (see illustration 5). 
Illustration 5: The parking garage below the green scenery

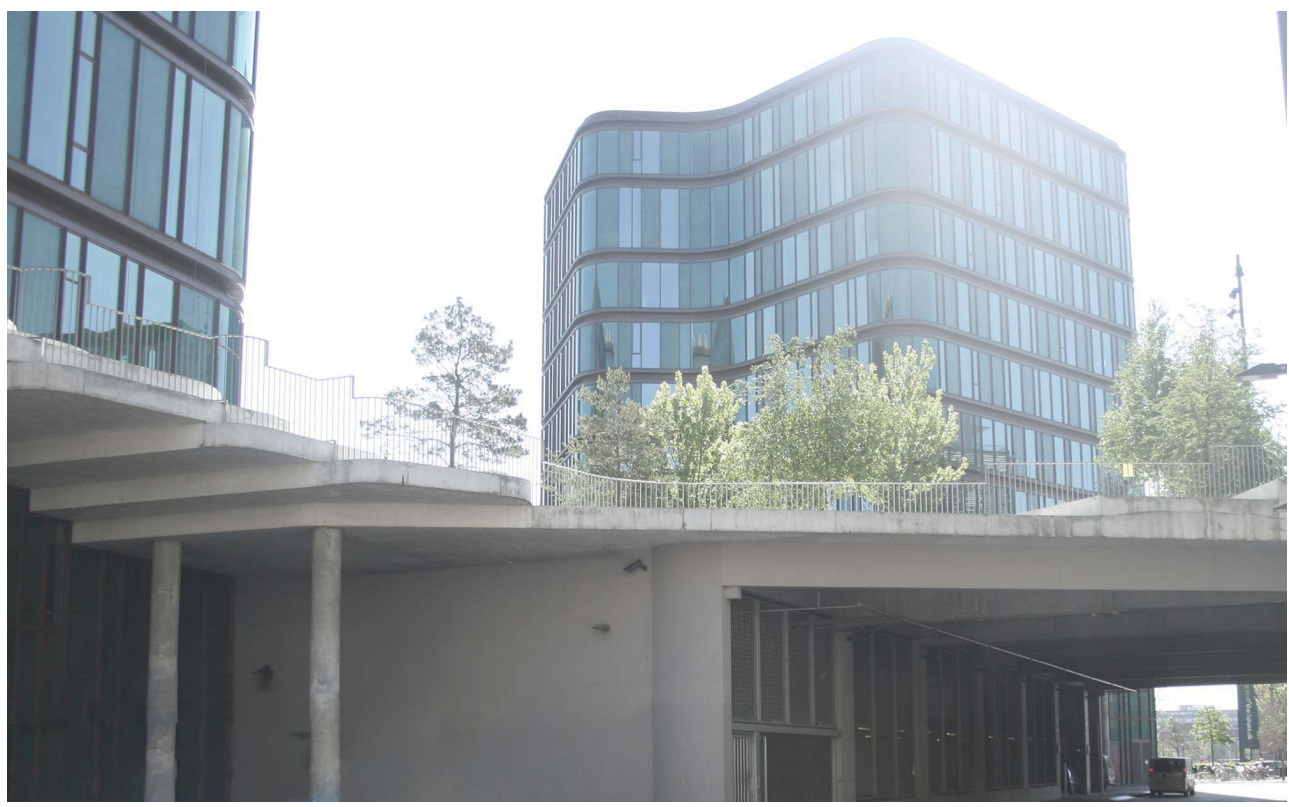

SOURCE AND COPYRIgHT: AUTHORS.

\section{Continuity of space}

This poetry is present in the façade as well, thus extending from the urban surface and into the construction of the architectural volume. Traditionally, the façade is understood as the physical divider between architecture and urban design; here, it introduces a different spatial experience, created by visually continuing the concrete curvatures through the glass membrane. The curved, exterior concrete slabs morph into the interior staircase landscape, creating a distinct tectonic spatial relationship between the two. For SEB bank, as an institution interested in nurturing a positive relationship with the city and its inhabitants, this ambiance is important, and by blurring the boundary between what is public and private, they facilitate the desired relation between SEB bank and the local community. Metaphorically, the relationship between the bank and the public is physically constructed through the design of this detail (see illustration 6).

On a general level, the urban landscape is a complex, fluid and diverse matter that entails concentrations of built up areas, landscapes and infrastructures. In landscape urbanism, the landscape is the connecting matter between architecture and the city, and in that capacity, it becomes the crucial space that demands our focus as architects and urban designers. The term 'urban landscape' covers the various urban concentrations and thus, by understanding the present urban situation through the notion of urban landscape, it is implied that the urban as well as the landscape are of equal importance and exist in different variations, where neither the urban nor the landscape is more present than the other (Laursen \& Lanng, 2017; Koolhaas, 1995; Koolhaas, 2001). The relationship is described by Corner as:

"Same, yet different; mutually exchangeable, yet never quite fully dissolved, like a new hybrid ever dependent upon both the $\mathrm{x}$ and the $\mathrm{y}$ chromosome, never quite able to shake off the different expressions of its parents." (Corner, 2006, p. 24) 
Illustration 6: The concrete curvatures continue from exterior to interior through the glass membrane

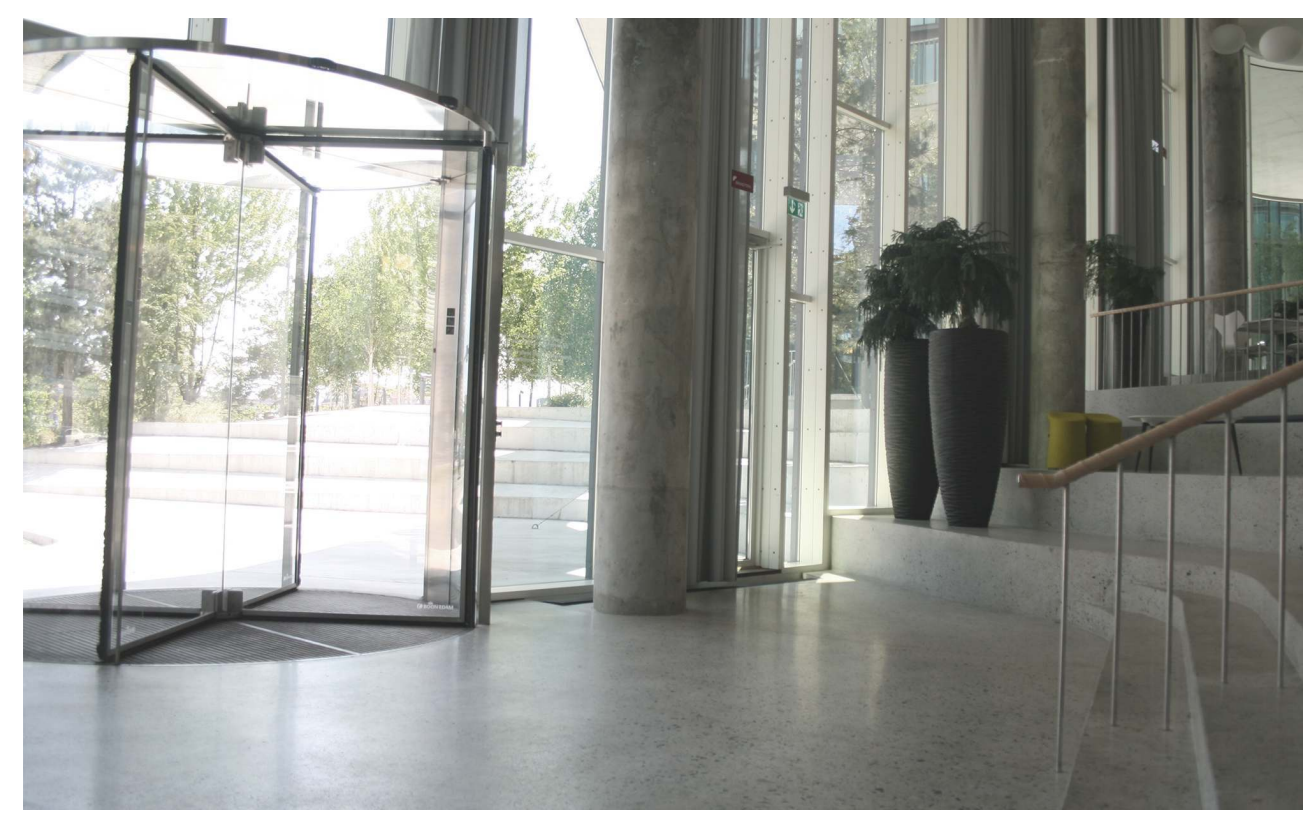

SOURCE AND COPYRIgHT: AUTHORS.

Therefore, the coexistence of the urban and the landscape is seen as a situation where both are always present, in different intensities, interwoven with and interdependent on each other. However, whereas landscape urbanism has its strength in describing this at a conceptual level, it can be questioned whether it is applicable to the actual materiality, tactility, and spatial experience. The juxtaposition of the building and the landscape is evident in the bank development. We can understand a connection between the building and the scenery and we can see the interweaving principle, when the space flows between the exterior and the interior. The distinction between what is a part of the urban landscape and what is a part of the building is blurred; interior and exterior spaces that are otherwise conceived as separate instances appear in correlation across scale, surface and volume. Kenneth Frampton's tectonic studies in architecture read architectural expression as a process comparable with the hermeneutic circle; that is to say, part understood in relation to the whole, and the whole understood through the accumulation of its parts (Frampton, 1995). Hence, the mental construing of architecture is linked to its physical construct as a detail.

\section{The detail}

This understanding precedes a description provided by the Italian architect Marco Frascari. He engaged himself in architectural details, specifically joints, as mediators of ambiance in architectural compositions:

"The joint, that is the detail, is the place of the meeting of the mental construing and the actual construction." (Frascari, 1984, p. 26)

21 According to Frascari, what justifies consideration as a detail depends on the scope, as the physical size of a detail depends on the point of observation. In this perspective, architecture can be read as a collection of architectural details making up the whole, and similarly the city can be understood as a compilation of urban details. In following this 
line of thought, the notion of tectonics opens the way for a fluent understanding of the relation between architectural volume and urban surface, as can be observed in the SEB bank, in which the experienced ambiance of a space is manifested in the technical materiality of its detailing, independent of scale. The detail could be comprehended as the fundamental physical object exposed to manipulation that architects and urban designers can influence to achieve the desired ambient qualities. Tectonics can thus be understood as a possible critical means for improving the spatial link between urban design and architecture, by offering a framework for aesthetically and technically joining the built environment across different scales. However, within architecture this focus upon detailing implied in tectonic architectural theory can also be misinterpreted as a deficient fascination with the detail and its technological and crafted manifestation itself, as is the case in the current focus on the tectonic potential of specific materials and technologies (Reiser \& Umemoto, 2006; Oxman \& Oxman, 2010). Thus, the detail is not relevant if it is not set into a site-specific context, relating the detail to the totality of the building and the city. It is our observation that the specific relationship between the artificial, green scenery and the overall landscape in the urban concept can be read as an example of this possible tectonic relation. In this interpretation, a potential is opened up for establishing a connection between developments in landscape urbanism and tectonic architectural theory, with the detail as a focal point of intersection and conceptual strength.

Landscape urbanism has been criticised for being too focused on the processes and appearances of nature, avoiding dealing with the principles of nature (Andersson, 2012). This weakness in landscape urbanism is possibly addressed by the introduction of a focus on the linking of architecture and urban design as an actual physical joining of urban surface and architectural volume derived from tectonic architectural theory. From this critique, terms like 'process urbanism' and 'ecological urbanism' have established themselves as specialisations closely related to landscape urbanism. What they have in common is an understanding of the city where, as actors, everything affects everything else, keeping things in a constant flow, assuring survival and nurturing development in a processual dynamic inspired by ecology:

“... the complexity of interaction between elements within ecological systems is such that linear, mechanistic models prove to be markedly inadequate to describe them. Rather, the discipline of ecology suggests that individual agents acting across a broad field of operation produce incremental and cumulative effects that continually evolve the shape of an environment over time." (Corner, 2006, p. 29)

In this understanding, careful control and management of the city is abandoned in favour of an engagement with the changeable, the unfinished and the unknown (Andersson, 2012):

"The city, for all its importance, can no longer be thought of only as a physical artifact; instead, we must be aware of the dynamic relationships, both visible and invisible, that exist among the various domains of a larger terrain of urban as well as rural ecologies." (Mostafavi, 2010, p. 29)

In the bank, the relationship between the scenery and the buildings can be described in terms of ecology because of its characteristics as a detail at the urban scale. While the buildings provide space for trees and grass to grow, they in return cool and clean the air, manage rainwater, and facilitate a higher biodiversity for the benefit of the locals and the people working there. The outcome is an ecosystem where liveable and ambient qualities are the result. Theories in landscape urbanism focus on describing the city and its 
buildings on a conceptual level, and it has been argued that it has yet to fully grow into its own form (Waldheim, 2010, p. 24; Duany \& Talen, 2013). From this limitation, we see a potential in juxtaposing landscape urbanism with tectonic architectural theory, benefiting from tectonics' concern with spatiality, ambiance and liveable qualities through careful utilisation and application of technology. But are tectonics, as related to spatial experiences in the human scale, interesting when discussing the design of cities? The Danish landscape architect Torben Dam has previously attempted to answer this question. He sees tectonics' greatest assets when dealing with our perception of spatial surroundings, and according to him this applies to landscape architects. He elaborates and describes the potential of tectonics as a principle of linking all the disciplines concerned with designing the urban environment (Dam, 2007). We have ourselves explored this potential in urban design education at Aalborg University (Hvejsel, Laursen \& Kierkegaard, 2017), and this paper can be seen as an attempt to extend this work into a theoretical and analytical framework for an 'urban tectonic' approach to design.

In this regard, the above re-reading of tectonic architectural theory opens up a potential to apply these theories in a critical reading of our surroundings in general, and thereby enables a movement towards a tectonic approach to urban design that links urban ambiance with the actual physical joining of structural elements in the built environment. By introducing a critical relationship between the two, tectonic theories are directed towards describing the actual ambiance, and facilitate a link between theory and practice by entering into a discussion of not only what defines the ambient qualities of a given space, but also how these ambient qualities are achieved at a methodological level. In SEB bank, the vision of nurturing a relationship with the local community has been physically translated into an enchanting, artificial, green urban scenery; a gateway where curved, concrete slabs visually flow in and out of the buildings, through the glass membrane, uniting the interior and exterior landscapes, juxtaposing architectural and urban ambiance. Looking closer at the façade, the horizontal curves along the building envelope dominate the visual appearance. The curves are an articulation of the construction method used in the buildings. As the buildings are a variation of a columnplate system with load-bearing cores, the façade has no important constructional purpose. Instead of covering the buildings with a planar envelope, the architects chose to visually demonstrate this tectonic principle in the façade by a horizontal retraction which creates a horizontal orientation that, together with the curved copper plates, adds to the visual reading. In this perspective, it is the tectonic details that unite the experience of the landscape and buildings by mimicking soft landscape curves, which together with the artificial, green scenery complete the metaphorical experience of the Swedish mountain landscape. The structure becomes almost poetic (see illustration 7). 


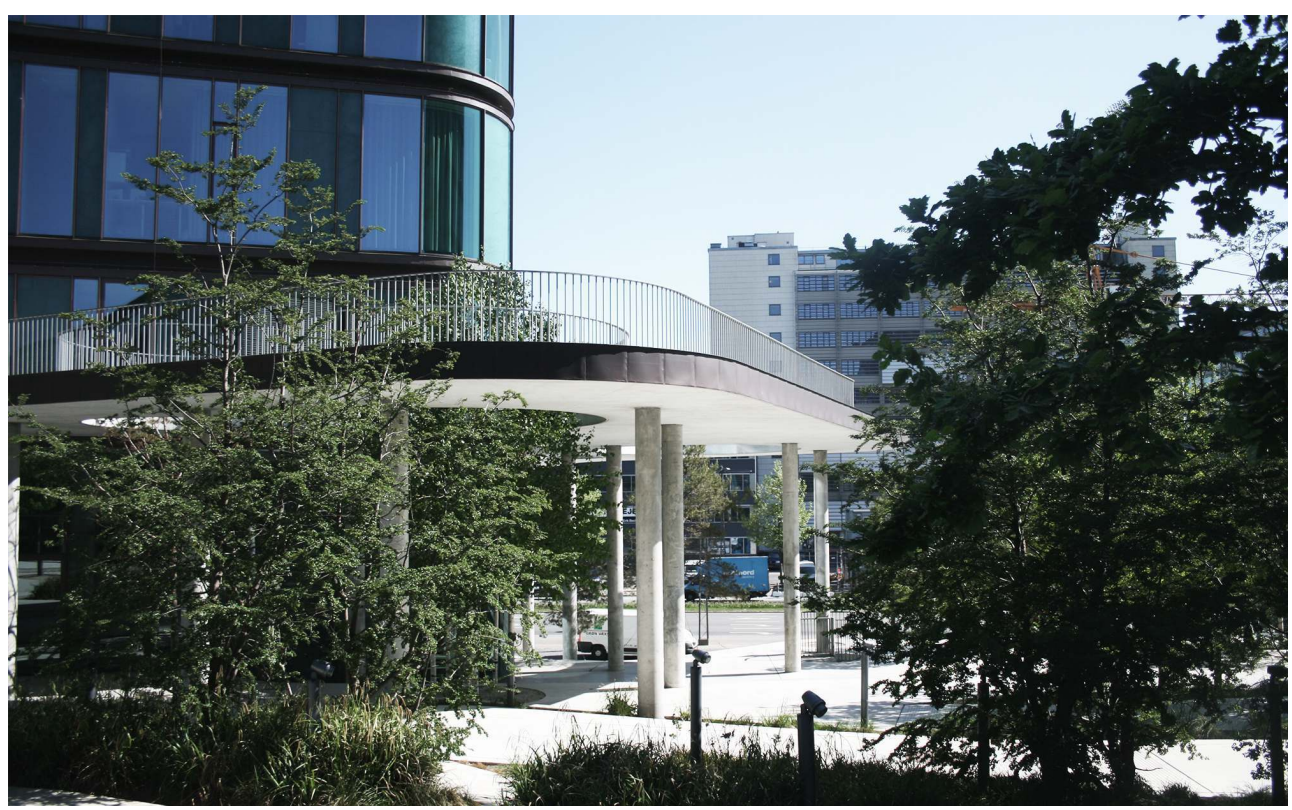

SOURCE AND COPYRIgHT: AUTHORS.

\section{Discussion: Towards a tectonic approach to urban design?}

In this paper, we have juxtaposed the disparate theories of landscape urbanism and tectonic architectural theories in two parallel tracks: theoretically, by conceptually linking the two, and with an analysis of a unique, tertiary building development in Copenhagen through a lens of both. This combination of theory development and analysis of a physical example that makes up the above case study has opened up the potential to discuss and address the strengths and weaknesses of landscape urbanism and tectonic architectural theory respectively. The motivation for this choice of research and casestudy design was, at a general level, the intention to zoom in on the general challenge of linking architecture and urban design. In this respect, the case study has enabled a linking of theoretical argument and analytical observation, thus outlining an 'urban tectonic' approach to urban design focused on the construct of the detail by (see illustration 8).

\section{Considering across scales the role of the detail in relation to the whole urban ecosystem}

The relationship between the parts and the whole can be tectonically described through Frascari's notion of the detail, which Frampton relates to the hermeneutic circle, thus positioning it in relation to the process of creation. Juxtaposing this with the ecological thinking present in theories of landscape urbanism, it widens the perspective when describing qualities in architecture and urban design. This establishes a relationship between the disciplines, between the scales, creating a notion that is able to describe qualities across scales while dealing with the layers of the city and their 
interrelationships. It is our observation that such an 'urban tectonic' approach is recognisable in the reading of SEB bank as a gateway into the overall green landscape, and the relationship between the green scenery and the building (see illustration 6). The open-ended and processual approach in landscape urbanism described by Waldheim and Corner was originally meant to establish a relationship between former boundaries between disciplines in architecture and urban design. By approaching the articulation of the surface, tectonically spatial qualities become the means that facilitates this coherence. And as stated in the analysis, the juxtaposition creates spatial qualities that extend the cumulative qualities of its parts. In the bank building, this principle is present in the spatial relationship between the exterior artificial green scenery and the interior ground floor, connected in a spatial landscape (see illustration 9).

Illustration 8: Consider across scales the role of the detail in relation to the whole urban ecosystem

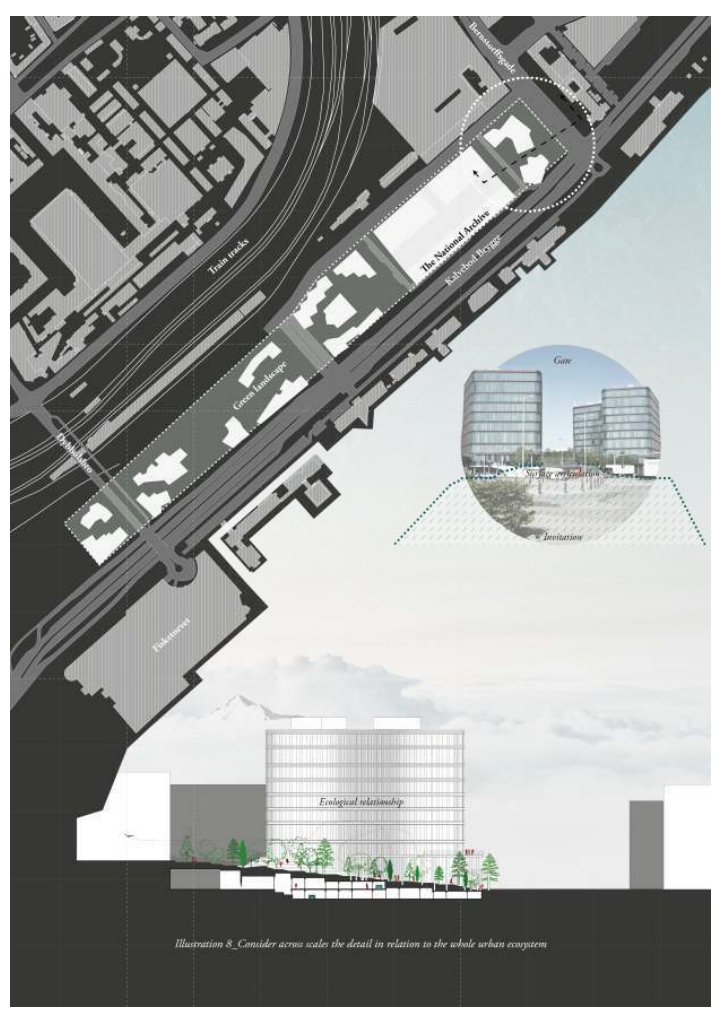

SOURCE AND COPYRIgHT: AUTHORS. 


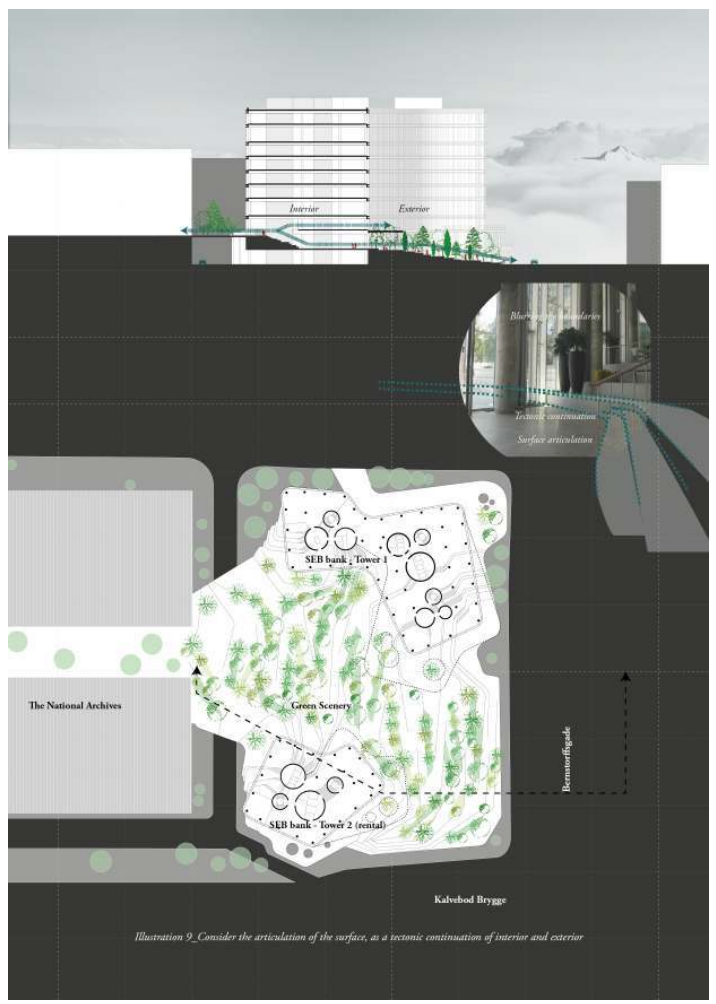

SOURCE AND COPYRIgHT: AUTHORS.

\section{Considering the articulation of the surface as a tectonic continuation of interior and exterior}

With this outline of an 'urban tectonic' approach to urban design, the otherwise intangible question of ambiance in our cities is described as a critical crossing of traditional boundaries between disciplines in architecture and urban design. Whereas the current analysis is just a small example, it has uncovered a series of potentials for juxtaposing architecture and urban design, as the development combines bank, parking garage and urban space. Volume and surface are tectonically joined as a detail on the urban scale, the appearance of which is understood as a gateway to experience and encounters crossing the layers of society and multiple user groups. To reveal further potential, additional examples must necessarily be analysed, and such a tectonic approach to urban design and architecture must be critically nurtured and implemented. However, one thing is certain: namely, that if we are supposed to live more densely in the future, it is of utmost importance to start developing cities and buildings, landscape and city, architecture and urban design by thinking of the technical challenges outlined in the introduction as potentials for forming novel ambiances in the city. Furthermore, densification forces us to consider new potential grounds if we are still to have highquality urban environments in our cities in the future. The analysis of the SEB bank and the subsequent theoretical studies have shown the potential of an otherwise hermetically closed building typology, tectonically transformed into a viable urban ambiance. 


\section{Conclusion}

In conclusion, this paper outlines a set of preliminary principles for an 'urban tectonic' approach to architecture and urban design, opening up a promising perspective for the future integration of architecture and urban studies. Observations in the specific case study, running in parallel with studies of a possible linkage of landscape urbanism and tectonic architectural theory, have provided a novel framework for discussing, developing, and ultimately increasing the sense of urban ambiance by linking it to the constructive solution of spatial details across scale. We believe that this is an interesting new take on the subject of designing cities and an interesting step in a direction towards blurring traditional boundaries between the disciplines of architecture and urban design, and towards an integrated approach to designing liveable cities. The central element in developing such a tectonic approach to urban design is the physical solution of details that bridge aesthetics and technique, architectural volume and urban surface. Firstly, this emphasises our task as urban designers and architects of envisioning ambiance in the future city, and secondly, that of necessarily linking it to an in-depth knowledge of the technologies that govern construction and planning practice. Pursuing this task in further research forms an interesting and present challenge with which we are in the process of engaging.

\section{BIBLIOGRAPHY}

Andersson, S.L. 2012. Processurbanisme - Byen som økosystem. Landskab, nº 1/2012, p. 15-17.

Appleyard, B.; Ferrel, C.E.; Carroll, M.A. \& Taecker, M. 2014. Toward Liveability Ethics: A Framework to Guide Planning, Design and Engineering Ethics. Proceedings of Transportation Research Boards 93 ${ }^{\text {rd }}$ Annual Meeting. Washington D.C., USA, January 12-16, 2014.

Böhme, G. 1998. Atmosphere as an aesthetic concept. Daidalos. vol 68, p. 112-115.

Corner, J. 1999. Recovering Landscape. New York: Princeton Architectural Press.

Corner, J. 2006. Terra Fluxus. in Waldheim, C. (ed.). Landscape Urbanism Reader. New York: Princeton University Press.

Dam, T. 2007. Does Tectonics make meaning in Landscape Architecture? Proceedings of the Tectonics Making Meaning Conference 2007, 10-12 December 2007, Eindhoven, Netherlands. Eindhoven: Eindhoven University of Technology.

de Geyter Architects, Xaveer. 2002. After-Sprawl. Research for the Contemporary City. Rotterdam: NAi Publishers.

Duany, A. \& Talen, E. 2013. Landscape Urbanism and its Discontents - Dissimulating the Sustainable City. Gabriola Island, Canada: New Society Publishers.

EM-DAT. 2016. The CRED/OFDA International Disaster Database. Brussels: Université Catholique de Louvain. Available online at: http://www.emdat.be (consulted on 13/05/2016). 
Frampton, K. 1995. Studies in Tectonic Culture: The Poetics of Construction in nineteenth and twentieth century architecture. Massachusetts: MIT Press.

Frascari, M. 1984. The Tell-the-Tale Detail. VIA. nº 7, p. 23-37.

Gehl, J. 1987. Life between Buildings. London: Island Press.

Gehl, J. 2010. Cities for People. London: Island Press.

Hvejsel, M.F.; Laursen, L.L.H. \& Kirkegaard, P.H. 2017. Gesture and Principle in Urban Tectonics An Educational Case Study. Nordic Journal of Architectural Research. vol 29, $\mathrm{n}^{\circ} 1$.

Koolhaas, R. 1995. S, M, L, XL. New York: Monacelli Press.

Koolhaas, R. 2001. Junkspace, in Chung, C.J.; Inaba, J.; Koolhaas, R. \& Leong, T.S. (eds.) Project on the city 2. Cologne: Taschen, p. 408-421.

Københavns Kommune. 2006. Lokalplan. $n^{\circ} 403$, “Rigsarkivet”. Available online at: http:// www.klimatilpasning.dk/media/296979/1_403.pdf (consulted on 27/10/2016).

Laursen, L.L.H. \& Lanng, D.B. 2017. Urban snapshots along journey trajectories. Nordic Journal of Architectural Research (Accepted, in press).

Lundgaard \& Tranberg. 2017. SEB Bank \& Pension. Available online at: http://www.ltarkitekter.dk/ seb/ (consulted on 26/09/2017).

Mostafavi, M. 2003. Landscape Urbanism. A Manual for the Machinic Landscape. London: Architectural Association.

Mostafavi, M. 2010. Why Ecological Urbanism? Why now? in Mostafavi, M. (ed.) Ecological Urbanism. Baden, Switzerland: Lars Müller Publishers.

Oxman, R. \& Oxman, R. (eds.). 2010. The New Structuralism: Design Engineering and Architectural Technologies. Architectural Digest. July 2010.

Palasmaa, J. 2005. The Eyes of the Skin. West Sussex, England: John Wiley \& Sons.

Reiser, J. \& Umemoto, N. 2006. Atlas of Novel Tectonics. New York: Princeton Architectural Press.

Sekler, E.F. 1964. Structure, Construction, Tectonics. In: Kepes, G. (ed.) Structure in Art and in Science. London: Studio Vista, p. 89-95.

Semper, G. 1989 [1851]. The Four Elements of Architecture and Other Writing. Trans. Mallgrave, H.F. \& Herrmann, W. Cambridge: Cambridge University Press.

Semper, G. 2004 [1861]. Style in the Technical and Tectonic Arts; or, Practical Aesthetics. Trans. Mallgrave, H.F. Santa Monica: Getty Research Institute.

SLA. 2017. City Dune. Available online at: http://www.sla.dk/en/projects/city-dune (consulted on 26/09/2017).

UN. 2014. World Urbanization prospects, the 2014 Revision. Available online at: http:// www.esa.un.org/unpd/wup/highlights/wup2014-highlights.pdf (consulted on 22/12/2015).

UNU-IHDP \& UNEP. 2012. Inclusive Wealth Report 2012 - Measuring progress toward sustainability. Cambridge University Press. Available online at: http://www.unep.org/pdf/IWR_2012.pdf (consulted on 13/05/2016).

Vischer, R. 1994 [1873]. On the Optical Sense of Form: A Contribution to Aesthetics, in Mallgrave, H. F. \& Ikonomou, E. (eds.). Empathy, Form, and Space: Problems in German Aesthetics, 1873-1893. Santa Monica, California: Getty Center for History of Art and the Humanities, 1994. 
Waldheim, C. (ed.). 2006. The Landscape Urbanism Reader. New York: Princeton University Press.

Waldheim, C. 2010. On Landscape, Ecology and other modifiers to Urbanism. Topos: European Landscape Magazine. $\mathrm{n}^{\circ}$ 71, p. 20-24.

Waldheim, C. 2016. Landscape as Urbanism: A General Theory. New York: Princeton University Press.

Wall, A. 1996. Programming the urban surface in Corner (ed.). Recovering Landscape. New York: Princeton Architectural Press.

WHO. 2016. WHO Global Urban Ambient Air Pollution Database. Available online at: http:// www.who.int/phe/health_topics/outdoorair/databases/cities/en (consulted on 13/05/2016).

Wölfflin, H. 1994 [1886]. A Prolegomena to a Psychology in Architecture, in Mallgrave, H. F. \& Ikonomou, E. (eds.). Empathy, Form, and Space: Problems in German Aesthetics, 1873-1893. Santa Monica, California: Getty Center for History of Art and the Humanities, 1994. p. 149-182.

Zumthor, P. 2006. Atmospheres. Berlin: Birkhäuser.

\section{ABSTRACTS}

Urban challenges derived from climate prospects and densification call for a renewed engagement with the question of the liveability of the built environment. Within this context, the economic and technical concept of our cities is an increasingly dominant aspect, whereas the fragile but vital question of ambiance that seemingly signifies our sense of liveability is often suppressed. This requires us, as architects and urban designers, to refine our descriptions of ambiance as an integral part of the technical construction principles applied in the built environment, hereby considering it a continuous space, as suggested in theories of landscape urbanism. By recalling the etymological meaning of tectonics as a contextual joining of aesthetics and technology at the architectural scale, the paper states that this can be understood as a tectonic challenge which crosses the architectural and urban domains. As a result, the potential is opened up to develop further the theory of landscape urbanism by juxtaposing it with tectonic architectural theory. The paper investigates this potential through a combined conceptual and analytical case, studying whether it is possible to define and describe urban ambiances across scale, in relation to the concept of the built environment, when applying an "urban tectonic" perspective.

Les défis urbains dérivés des perspectives climatiques et de la densification urbaine demandent un engagement renouvelé dans la question de l'habitabilité de l'environnement bâti. Dans ce contexte, la dimension économique et technique de nos villes revêt un aspect de plus en plus dominant alors que la question délicate mais vitale des ambiances, qui semble refléter notre sens de l'habitabilité, se voit fréquemment éludée. En qualité d'architectes et de designers urbains, cela nous oblige à préciser nos descriptions des ambiances en tant que partie intégrante des principes de construction technique appliqués à l'environnement bâti, et par-là, à les considérer comme un espace continu tel que le suggèrent les théories d'urbanisme paysagiste. En rappelant le sens étymologique de la tectonique comme une liaison contextuelle de l'esthétique et de la technique à échelle architecturale, l'article établit que cela peut constituer un défi tectonique qui dépasse l'échelle architecturale mais aussi urbaine. C'est ainsi qu'apparaît la possibilité de développer plus avant la théorie de l'urbanisme paysagiste en la juxtaposant à la théorie architecturale tectonique. L'article étudie ce potentiel à travers un cas à la fois conceptuel et analytique en examinant s'il est possible de définir et de décrire les ambiances urbaines à travers 
les échelles, par rapport au concept d'environnement bâti, par l'application d'une perspective de «tectonique urbaine ».

\section{INDEX}

Mots-clés: Design Urbain, Architecture, Urbanisme Paysager, Tectonique, Habitabilité, Ambiance

Keywords: Urban Design, Architecture, Landscape Urbanism, Tectonics, Liveability, Ambiance

\section{AUTHORS}

\section{ELIAS MELVIN CHRISTIANSEN}

Elias Melvin Christiansen (M.Sc.Eng. in Architecture) is a PhD student at the Department of Architecture, Design and Media technology, Aalborg University. His research is placed within the field of Urban Tectonics, investigating the critical spatial relationship between the architectural volume and the urban surface.

emch@create.aau.dk

\section{LEA HOLST LAURSEN}

Lea Holst Laursen (PhD, M.Sc.Eng. in Urban Design) is Associate Professor at the Department of Architecture, Design and Media Technology, Aalborg University. Her research is placed within the fields of urban transformation and spatial restructuring, with a focus on differentiated urban development tendencies and site transformation. Research within these fields includes landscape development strategies, urban design, regional development and tourism studies.

llhl@create.aau.dk

\section{MARIE FRIER HVEJSEL}

Marie Frier Hvejsel (PhD, M.Sc.Eng. in Architecture) is Associate Professor at the Department of Architecture, Design and Media Technology, Aalborg University. Since 2007, she has published several peer reviewed research papers and participated in international conferences on the topics of Tectonics and Interiority. In 2010, she was awarded the Annual Award for Excellence by the international journal "Design Principles and Practices". Besides her academic career, Marie Frier is a practising architect and a partner in the firms www.frierarchitecture.dk and www.frieraarhus.dk mfri@create.aau.dk 